\title{
The Position of South African Children's and Youth Literature in Librarian Training in South Africa
}

\author{
GENEVIEVE HART \\ Department of Library \& Information Science, \\ University of the Western Cape, \\ Cape Town, South Africa 7535 \\ ghart@uwc.ac.za
}

\begin{abstract}
A survey of 16 South African library schools was undertaken to identify children's literature courses. Eighteen courses were found at eight institutions. The lecturers responsible were then interviewed - giving details of course content, resources available and their perceptions of their challenges. The courses are clearly under threat and very little emphasis is placed on South African literature. The intervention of the Library and Information Association of South Africa and library organisations is called for.
\end{abstract}

\section{INTRODUCTION}

The paper reports on an investigation into the position of children's literature (specifically South African children's literature in all our languages) in the training of librarians in South Africa. Its starting point is the belief that there are two basic necessities for children's reading: "interesting material that makes sense to the learner and an understanding adult as a guide" (Wray, Bloom \& Hall, 1989: 82). The project assumes that teachers and librarians - as "enabling adults" (Chambers, 1993) - have a significant influence on the reading patterns of children and that their own training must influence what they promote in their classrooms and libraries.

In reporting on the education and training of librarians, the paper focuses on what amounts to a pilot of a larger study. This larger project will investigate the position of children's literature in teacher education and training throughout South Africa and also in academic language departments at South African universities.

As elsewhere in the world, in South Africa children's literature has been largely the domain of librarians. Library schools within universities were the strongholds of children's literature research - building and managing research collections like Iskemus at the University of Stellenbosch, the Children's Literature Unit at Potchefstroom University for Christian National Education and the Children's Literature Research Unit at UNISA. The professional association SAILIS (now disbanded) was responsible for our major children's literature prizes. And as elsewhere, knowledge of children's books was seen as a crucial competency for those working in public and school librarianship. Internationally public and school librarians are assumed to be the "guardians of children's literature", to "value book knowledge", and "to provide a variety of training in literature development" (Reading the future, 1992: 42). 
However the international literature reveals that the place of children's literature in librarian training has weakened as fewer graduates find work in public libraries and as the field in increasingly pre-occupied with information and communication technologies. If this international trend applies in South Africa there are disturbing implications as the role of librarians in a country such as South Africa - where the majority of children do not experience "print-rich" homes - is arguably especially significant.

\section{Brief description of LIS training In South Africa}

It is necessary to give some brief summary of librarian training structures in South Africa so that the context of the research project is understood. Traditionally there have been three avenues for first professional training:

- the four-year BBibl degree - offered by departments of library and information science within universities. (The names of the library schools have undergone change over the years with many recently preferring the name Department of Information Studies. However the old generic term "library school" still is in common use).

- the one year postgraduate Diploma of Library and Information Science - offered by library and information science departments within universities.

- the three year National Diploma in Library Practice - offered from the mid 1980s by the Technikons. In the past ten years, this diploma course, originally designed for so-called para-professionals, has evolved into a four year BTech degree.

South African LIS schools have traditionally offered generalist training for all kinds of libraries - with some opportunities to specialise offered by a limited choice of options. Thus children's literature would typically be offered as an optional module. Further specialist options might be offered at postgraduate level.

Specialist training in school librarianship is provided for in three ways:

- optional modules within the teacher training diplomas and certificates at teacher training institutions.

- from the late 1980s the one-year Diploma in School Librarianship run by the LIS schools and designed for qualified teachers.

- four year BBibl Ed degrees that combine professional librarian and teacher education.

The recent national audit of school libraries (Department of Education, 2000) does not detail the professional qualifications of what it calls "library educators"; but my guess is that many school librarians in South Africa hold the generalist BBibl or postgraduate diplomas described previously. Some of the education departments prior to 1994 did insist that school librarians had teacher qualifications as well. (Here I should point out that nationally less than $30 \%$ of our schools have on-site libraries and most are in the hands of full-time classroom and subject teachers). As for children's and youth staff in public libraries, my study of 67 Cape Town children's libraries in 1999 found that only $49 \%$ of them had any professional qualification (Hart,1999). 


\section{BACKGROUND AND RATIONALE}

The impetus for the investigation reported on in this paper comes from two areas of concern - the state of children's publishing in South Africa and the state of children's reading.

\section{Children's publishing in South Africa in crisis}

The project is rooted in concern that children's and youth literature in South Africa is under threat. The dominance of multinational publishing houses and the small size of our book-buying market mean that it is usually cheaper to import books than to produce homegrown ones (Machet, 1993). Only a handful of original books in African languages are being published each year - this in a country whose constitution stresses the right of each of our 11 languages to be developed and where official policy is that children be educated in their mother tongues. In the last few years, a major children's picture book publisher has gone bankrupt. Another, which specialises in translating the world's prize-winning picture books into our indigenous languages, has held back its publishing of a number of manuscripts as it cannot be sure of the minimum number of sales to cover costs.

Traditionally the book industry in South Africa has relied on the educational and library market as only a tiny minority of South Africans buys books. However in recent years patterns of purchasing within the public library structures and the education departments have changed. For example, the Western Cape province was split into three in the late 1990 s which means that the new Western Cape library structure is buying far less. The library structures of the two new provinces are still finding their feet. Another factor is that public libraries are being forced to spend more on textbooks and curriculum support materials as the new curriculum, Curriculum 2005, has brought a huge increase in project work but no increase in school library provisioning (Hart, 1999). Site-based management of schools has meant that schools control their own budgets - so the old bulk central purchasing of books by school library support services has gone.

The weak state of children's publishing in South Africa is worrying to those who believe that a national literature is crucial to the "nation-building" that a divided society like ours so clearly needs. There is concern in post-colonial countries that children who are brought up on a diet of foreign books lose touch with their own cultures and values. Maddy and MacCann warn that even recent writing about Africa and within Africa reinforces "the hegemony of the West and the myth of white supremacy" (1996: 12). This belief is shared by book activists in other post-colonial societies who see books as "instruments of educational development, social growth, cultural preservation and meaningful communication" (Formulating the National Book Policy, 1993: 19).

The construct of the African renaissance is being promoted by the South African government as an ideology to restore pride and a sense of common identity in post-colonial and post-apartheid South Africa. Since democracy in 1994, South Africa has embraced, in its constitution and its official policy documents, the ethos of multilingualism and multiculturalism - in which previously marginalised cultures and languages are given equal opportunities and value. I look with interest at the writing on the history of Canadian children's literature that suggests that a children's literature can be a vehicle for the building of a sense of heritage and identity (for example Saltman, 1987; Paul, 1989; Carpenter, 1996). 
Apart from the ideological issues, there are more pragmatic reasons to foster a homegrown publishing industry. The production of good juvenile literature in local languages might well foster the reading habit (Formulating the National Book Policy, 1993: 20; Ogunrombi \& Adio, 1995: 55). There is much evidence that pleasure in reading in adulthood correlates generally with pleasure in reading in childhood (Reading the future, 5). Children learn to read by reading - the more they read the better they will become at it (Flanagan, 1995). And there is much evidence that the better they are at reading the more they will achieve academically in all areas of the curriculum. A prerequisite surely to pleasure and ease in reading must be access to attractive books that make sense to children. There is some debate in the literature over whether children want and need material set in their own environment (Sturges \& Neill, 1998: 151). Though some commentators claim that young readers prefer relevant material that reflects their own experience (for example Ogunrombi \& Adio, 1995), others have found that the need for so-called "relevance" might have been over-stressed (Radebe, 1995).

\section{$\underline{\text { Youth literacy }}$}

Our national education minister has declared 2001 to be the "year of the reader" amid much concern over the state of reading amongst young people in South Africa. Our provincial education department has just introduced a daily literacy half-hour to improve reading levels.

Recent studies conclude that reading and writing are being badly neglected in our schools (Taylor \& Vinjevold, 1999). There is general agreement that children might be learning the mechanics of reading in their primary schools but they are not acquiring literacy. The READ Educational Trust has contended that low reading levels account for the high failure rates in our schools (READ Educational Trust, 1998). My own research within a circuit of primary schools in Cape Town in 1998 and 1999 concluded that poor reading abilities were hindering learning across the curriculum (Hart, 2000a, 2000b). The teachers in these studies attributed many of the problems that they encountered in project work to the lack of reading fluency in their classes, but seemed unable to conceive of dynamic reading campaigns that might improve the situation. Their classroom reading collections and libraries were inadequate and there was very little emphasis on reading for meaning - let alone reading for pleasure. Although all the schools were within walking distance of wellstocked public libraries, they were making little use of these facilities.

\section{RESEARCH STUDY}

The above discussion has served to give the context of and rationale for the study of the position of children's literature in librarian education. Quite simply, even if we had a wonderful range of children's books, we would still need those "enabling" adults - teachers and librarians who are able to nurture the reading culture South Africa needs. Given the consensus that young children must have South African books, another urgent need is to find out what emphasis there is in librarian education on South African materials - and on materials in our indigenous languages. 
The research questions and methodology are grounded in the above concerns and also in previous research in the teaching of children's literature.

\section{$\underline{\text { Existing research }}$}

There is a strong strand of children's literature research in the South African library and information science literature - with papers that examine specific books and themes and also several that examine readership issues. Jenkins' article (1994) on the academic status of children's literature is a rare article on South African children's literature as a discipline.

Running through the international literature there are two threads of more specific interest to this study - namely, the reporting on teaching practices within library and teacher training institutions and discussion of the competencies required by children's and school librarians.

Signal, the English children's literature journal, for example has a series of articles in which faculty - either within academic departments, library schools or teacher training institutions - describe their practices and challenges (for example Hollindale, 1979; Paul, 1989; Williams, 1995). The themes of these Signal articles are still of current interest - as shown by a lively debate held on the listserv CHILD_Lit towards the end of 2000 . The debate - among teachers of children's literature in universities in the US - started off with a question over what level children's literature courses should be given within teacher training curricula. Should it be a senior course building on prior literary theory courses or could it be used to introduce students to literary theory? The discussion evolved into a debate on the status of children's literature as a field of study with some complaints that students and academic colleagues were still likely to see children's literature courses as easy options and that children's literature was "the stepchild of literary theory".

As signalled in the preliminary discussion above, of particular interest to South African research are those articles by educators in what might be called post-colonial countries and which address the issue of the choice of books to be included in their courses. The issue here is the status of indigenous literature in their courses as opposed to the literary canon from the UK and the USA. In 1989 Paul, for example, counted 161 courses in children's literature in tertiary institutions in Canada. Despite the fact that Canada had what she calls a "flourishing community of high quality children's writers" she still described the place of Canadian books as a "sensitive issue" and indeed found that only $20 \%$ of books taught in children's literature courses were Canadian (Paul, 1989: 43). She attributed this low figure to the residue of Canada's colonial past and its geographic position next to the giant market of the USA.

The second thread in the research literature of value to the study is the discussion of librarian education and the competencies required by school and children's libraries. Knowledge of children's literature is a fundamental competency of children's and school librarians as evidenced in official statements of policy of major professional associations. However, evidence from two major studies in the UK in the 1990s indicates an erosion in the position of children's librarianship in that country and also in the number of the specialist children's librarianship and literature options offered within the library and information studies schools (United Kingdom. Department of National Heritage, 1995; Elkin \& Lonsdale, 1996). 
My own study of 67 children's library staff in Cape town in 1999 found that $69 \%$ described themselves as "children's library specialists". However even these specialists were required to spend much of their day "helping out" at the adult circulation desk. Only $49 \%$ had a professional LIS qualification and $46 \%$ of these had completed one course in children's literature as part of their professional training (Hart, 1999). I have no such figures for our school librarians - but since the majority of South African school libraries are run by teachers in their "free" time I suspect that very few have had any training in children's literature. The next phase of my study will examine the position of children's literature in teacher education.

\section{RESEARCH QUESTIONS \& METHODOLOGY}

The above discussion has summarised the main themes in the literature and has highlighted those that are clearly relevant to the research problem.

The research questions I set out to answer include:

- What place does children's and youth literature have on the professional training curriculum? Has this position changed in the past few years?

- In existing children's \& youth literature courses what focus is there on South African writers and books?

- What attention is paid to the need for books in the vernacular?

- What do the teachers of children's literature courses see as their major challenges?

A questionnaire was drawn up with the intention to conduct personal and telephone interviews with the teachers of children's literature in all of the library and information science departments (or so-called library schools) throughout the country.

The questionnaire has four parts that gather data on the following:

- an overview of the programmes offered by the department and of all courses that might have some kind of children's literature component.

- personal details of the lecturers responsible for children's literature education in each school - age, gender, education.

- details of the children's literature courses such as duration, choice of books, assessment methods.

- resources available to the lecturers.

- the lecturers' views on the challenges of teaching children's literature in South Africa.

\section{$\underline{\text { Summary and analysis of data }}$}

Structured interviews, based on the questionnaire described above, were conducted with initially the chairperson of 16 schools of library and/or information science and then with the academic identified as the children's literature specialist within each school. The 
survey thus covered all but two of the LIS schools in South Africa. (The LIS school at the RSA Technikon could not be contacted and the interviews at the University of Zululand are not yet completed because one of the two children's literature lecturers there has been away).

The survey included four "ex-LIS schools" - schools that have closed in the past five years or are about to close - as it was thought that they might have useful insights into the state of LIS training in South Africa. Two of these four have been "transformed" into departments of Information Studies within Arts Faculties and now run courses in Information Studies within these faculties. Two of the existing library schools reported having no children's literature coverage - both having dropped it in the mid 1990s because of the pressures of falling numbers of students and moves towards information technology courses. It should be noted however that both of these two still claim to be providing first professional generalist training and both claim to place their graduates within public library and school services. Another LIS school is on the verge of dropping its one remaining children's literature course as it receives no crediting for the course which "belongs" to another faculty, the Education Faculty.

Thus the study includes eight library and information science schools that were found to be involved in children's literature education - six universities and two technikons. Any discussion of South African education has to allow for the impact of past-apartheid policies which established a number of ethnically based tertiary institutions - often in the rural "homelands". Six of the eight LIS schools are within what are known as "historically disadvantaged institutions" (HDIs) and two within "historically advantaged institutions" (HAIs).

Given South Africa's past, it is of interest that children's literature - and perhaps LIS training as a whole - seems to have lost favour among the historically advantaged (and historically white) institutions (HAIs). The four library schools in the survey that have closed are within HAIs and the two that have dropped children's literature are also within HAIs. Of concern is the fact that three of the four major resource collections for children's literature teaching and research in South Africa are placed within these HAIs. Meanwhile none of the rural historically disadvantaged LIS schools have any budgetary provision for the building of such resource collections. This will be returned to below.

\section{$\underline{\text { Survey of courses }}$}

In all, 18 courses were identified at the eight institutions that have some kind of children's literature content. Five of the schools provide one compulsory course as part of their first professional and generalist programmes. Only five of the 18 are standalone courses titled Children's and Youth Literature. Children's literature is often a section within courses called Readership, User studies, Literature studies and Children's library practice. In terms of hours devoted to children's books, there is little difference between the two groups - with standalone modules and children's literature components within larger courses comprising on average 23 hours of official formal contact time (the equivalent of a typical quarterly module). However a closer analysis of respondents' description of what is included in the children's literature components of courses labeled Readership in the universities and Literature Studies in the technikons reveals that they are sometimes no more than a general survey of the main genres and of selection criteria for children. Only two of these courses supply students with a core list of children's books to read - whereas all but 
one of the standalone children's literature courses do. Much seems to depend on the individual lecturer - for example one commented that, when she took study leave, the reading of children's books was dropped in her Readership course as her replacement was "not interested".

All of the children's literature courses are restricted to students enrolled at the LIS schools. One respondent mentioned that changes in the structures at their university had recently placed her department within a large school of related disciplines and that this might serve to open their courses to other students.

Five of the 18 courses might be described as "dormant" - they are optional postgraduate and BTech courses but no students enrolled for them last year or this year. Moreover the specialist Diplomas in School Librarianship, which all include children's literature modules, seem to be under threat throughout the country - and can also be best described as "dormant". Reasons given for the failure of these courses include students' preferences for ICT and management courses, shortages of jobs in school and public libraries, and lack of support for them from colleagues within the LIS schools. Respondents were unanimous that children's literature is losing ground at their institutions and that more time should be devoted to it. Several respondents pointed out that, given the lack of reading background of South African school leavers and the high illiteracy rates, reading courses should form the backbone of the curriculum.

\section{Teachers of children's literature}

Running through the open-ended questions that asked respondents what they see as their chief challenges there are many comments that reveal high levels of stress - perhaps brought by the turmoil in higher education circles and also by the lack of resources needed to support their teaching. Several reported that they are having to take on more and more courses as colleagues are retrenched and their posts frozen. Respondents frequently talked of the need for support from their colleagues and for more funds for course materials. There were many impassioned comments that the "digital divide" between information rich and information poor that pre-occupies so much of the attention of business and government will not be narrowed unless basic literacy is attended to.

As elsewhere in the world (Hunt, 1994:7), the teaching of children's literature in South Africa is on the whole in the hands of women of fairly junior status. The average age of the eight key respondents is 48 (the youngest is 43 ) and only one is male. Only two have professorial status or the equivalent. Four are English speaking, one is Afrikaans speaking, one is Xhosa speaking, one Setswana and one Sotho. The relatively high age of the respondents is of concern as is the fact that that six do not speak the first language of their students.

One of the eight lecturers has a $\mathrm{PhD}$ (with two about to complete theirs) and five have Masters degrees with three of these also holding professional teaching qualifications. Six studied children's literature in their own formal training.

One of the shortcomings of the survey is that it does not delve deeply enough into the respondents' theoretical knowledge of children's literature. If LIS children's literature courses are to have the respect of other academic disciplines, they need to be rooted in solid 
literary theory. Only three of the eight felt satisfied that were adequately informed about developments in children's literature. Six of the eight had not read a single children's or youth book in the three months before the interview. Such findings lead me to speculate that the courses on offer in our library schools are far from dynamic.

\section{Challenges of teaching children's literature in South Africa}

On asked what they saw as their chief challenges, all respondents talked of the lack of reading culture in South Africa and the lack of reading background of their students. All agree that they have to start from scratch. There were a few comments that we need to get our students to "uncover their oral story traditions". Another from a rural university said that her students seem to have gone "from an oral culture to a TV one".

The second most frequent comment concerns the shortage of African language books - especially in the so-called "smaller" languages. Only one respondent however mentioned her lack of knowledge of African languages as a problem and only one brought up the problems of providing for the language and cultural diversity in her classes.

Another frequent complaint was the lack of appreciation for literature courses among their colleagues and students - and, worryingly, among school teachers. Respondents feel apparently that they have constantly to defend their courses. Perhaps a contributing factor issue is what one respondent calls the prevalent "utilitarian" or "didactic" approach to reading in Africa. In this view, books are for education and self-improvement. The risk is that children's books might be dismissed as frivolous.

Shortages of resources are clearly a problem. Only one of the schools within HDIs has access to a collection of children's and youth books. Only two in all has some kind of annual budget to buy children's books. And only two of the respondents reported that they have multiple copies of titles so that groups of students can read and discuss the same key books - the value of which was commented on in the series of articles on children's literature education in the journal Signal mentioned above.

One of the themes in these Signal articles is the reward of getting young adults to return to their childhood reading and rediscover its joys. In South Africa it is clearly not a case of "REdiscovering" childhood joys but rather of discovering them. Two of the respondents did comment on how exciting it can be to witness the often sudden awakening of interest in students - even if these breakthroughs are rare.

\section{The status of South African books}

I must admit that my focus shifted in the course of the survey. As stated earlier, my research proposal had emphasised the need to investigate the status of South African children's literature - in all our languages. However I soon became pre-occupied with the status of children's literature in general!

The issue of providing for multilingual and culturally diverse classes is complex. The LIS school courses are given in English - the lingua franca - and largely focus on books in English (American, English and South African). On average, 20\% of the books discussed across all campuses are South African - though it has to be said that three of the respondents 
give no coverage of South African materials at all (surprisingly the three African respondents). Moreover only $17 \%$ of whatever theory and history is given deals with South African issues.

Comments in the open-ended question discussed just above indicate that there is an assumption that there just is not enough material in the vernacular and so nothing can be done. Perhaps a typical example is the second year Literature Studies course in one technikon, which covers adult literature in English, Afrikaans and Xhosa but children's literature in English and Afrikaans only. It does not include a component on Xhosa children's literature as, apparently, no Xhosa speaking children's literature teacher can be found. Only one of the respondents states that she explicitly encourages her students to include Xhosa language materials in their essays and in a project.

The most common defense of the "English-only" coverage is that the students have no background knowledge in children's books as the majority come from disadvantaged book-less homes and schools and so they need to have "the basics" - meaning the canon of children's literature from the West. One respondent commenting on the lack of background of her students told me "we can't assume that they have read what we read - if I refer to a fairytale I have to end up telling the whole story - they don't know what I'm talking about".

Of course the challenges of teaching students who have never been exposed to children's books and whose own literacy skills are weak are daunting. In one short module students have to be introduced for the first time to children's books and also be taught how to take that knowledge into their work.

\section{CONCLUSIONS}

The overall conclusion is that children's literature education in South African LIS schools has lost ground and that it is in a precarious position. There has been no increase in resources or support for it, even though the new wave of LIS students are mostly from disadvantaged schools and print-poor backgrounds. The educators expressed concern that they are training future public librarians who will go into children's and youth work with no grounding in children's literature. As one put it, "my heart is not well with my LIS courses anymore": Once this committed generation of children's literature educators retires then it is difficult to see who will take over.

The courses showed little awareness of the need for a South African children's literature. The belief in the power of literature to build cultural esteem and identity does not seem to have penetrated our LIS schools. It is further evidence of a move away from South African indigenous languages - as evidenced in a recent newspaper report that the number of students studying African languages at our universities has halved every year since 1995 (Students shun South African languages Sunday Times, 4 March 2001).

The position of Afrikaans children's literature education perhaps should be highlighted. The LIS schools within the Afrikaans universities like Stellenbosch, Potchefstroom and Unisa used to have a strong tradition of research and activism in the field. Afrikaans children's publishing is of high quality - largely perhaps owing to past 
government support (Machet, 1993). Yet now even Unisa has no Afrikaans books on its core list of books for its Honours course in children's literature.

\section{RECOMMENDATIONS}

This paper has given a snapshot of children's literature education in South African library schools. It shows that in South Africa we are in danger of losing our position as leaders in the field. It serves as a warning call, I believe, to LIASA (the Library and Information Association of South Africa), employers, especially the public library sector, government education departments and to our university and technikon managements.

LIASA is a young body and has needed time to establish itself. However it is time that it stepped into the education and training role required of a national professional association. Competencies need to be defined and library schools need guidance and support to ensure that their graduates have the desired competencies.

It is also time that it spoke with a louder voice on the weak state of school libraries in South Africa. This year has been declared "year of the reader" and LIASA might exploit the opportunity this gives librarians. Its annual conference this year has the theme "African renaissance". Perhaps it is time to move away from the pre-occupation with virtual and digital librarianship and take another look at our core business - reading and books and people.

Employers - the public and school library services - have a crucial role in the definition of and implementation of children's and school librarian core competencies. In recent years with the squeezing of their budgets and pressures on them to "transform", the major library employers seem to have abdicated this role.

My study of children's librarians in Cape Town, mentioned above, showed that the people running children's libraries were under-qualified and often had no special interest in working with children (Hart, 1999). If employers continue to appoint people as children's librarians who have no interest in or expertise in children's literature, then there is no incentive to library schools to continue with the hard work of providing this kind of education.

The message to library schools is that far more careful planning and coordination of courses is required. Collaboration between university departments and faculties - as well as between institutions is called for. This will require courage as many of the schools are living under the threat of closure and so might find it difficult to plan creatively.

Finally, there are encouraging signs that the crisis in children's literature is being recognised. The Centre for the Book in Cape Town has just hosted a wide cross section of stakeholders at a national symposium Creating one Voice. Its aim is to "form a South African Children's Literature network in the context of the African Renaissance". The time might well be ripe for a fresh look at the content of our children's literature courses and our teaching approaches. 


\section{REFERENCES}

Carpenter, C. (1996). Enlisting children's literature in the goal of multiculturalism. Mosaic, 29 (3), 53-73.

Chambers, A. (1993). Tell me: children, reading and talk. Stroud: The Thimble Press.

Department of Education. (2000). South African school library survey 1999. Pretoria: Department of Education \& Human Sciences Research Council.

Elkin, J. (1992). The Education and training of children's librarians. International Review of Children's Literature and Librarianship, 7 (3), 151-154.

Elkin, J., \& Lonsdale, R. (1996). Focus on the child: libraries, literacy and learning. London: Library Association

Flanagan, W. (1995). Reading and writing in junior classes. Cape Town: Maskew Miller Longman.

Formulating the National Book Policy: Need and Guidelines. Report of the UNESCO/APPREB Sub-Regional Consultation on National Book Policy and National Book Development Councils in South Asia, New Delhi 23 \& 24 August 1993. (1993). New Delhi: Afro-Asian Book Council.

Hart, G. (1999). Ready for the information society? A study of Cape Town's children's librarians. New Review of Children's Literature and Librarianship, 5, 169-188.

Hart, G. (2000a). "My kids hate to read up \& those things". Teachers, projects and reading: reflections on a field study of project work. WCED Literacy Indaba, Cape Town College of Education, Mowbray, 12-13 July 2000.

Hart, G. (2000b). Project work as a vehicle for information literacy education in a circuit of South African schools. IFLANET. Available online: www.ifla.org.

Hollindale, P. (1996). Re-reading the self: children's books and undergraduate readers. Signal, 79, 67-74.

Hunt, P. (1994). An introduction to children's literature. Oxford: Oxford University Press. Jenkins, E. (1994). What the academic study of South African children's and youth literature has to offer. South African Journal of Library and Information Science, 62 (4), 136-140.

Machet, M. P. (1993). Publishing and book selling in South Africa with specific reference to the black market. South African Journal of Library and Information Science, 61 (4), 166176.

Maddy, Y. L., \& MacCann, D. (1996). African images in juvenile literature: commentaries on neocolonialist fiction. Jefferson: McFarland.

Lonsdale, R., \& Spink, J. (1987). Children's books in the education of librarians at the College of Librarianship Wales, Aberystwyth. Signal, 55, 203-209.

Ogunrombi, S. A., \& Adio, G. (1995). Factors affecting the reading habits of secondary school students. Library review, 44 (4): 50-57.

Paul, L. (1989). Teaching children's literature in Canada. Signal, 58, 39-74.

Radebe, T. (1995). Reading interests of Zulu-speaking Standard Two children in Pietermaritzburg. South African Journal of Library and Information Science, 62 (4), 161 172.

READ Educational Trust. (1998). No South African child should fail matric: a submission to all involved in the education of South Africa's children. Braamfontein: Read.

Reading the future: a place for literature in public libraries. (1992). London: Arts Council of Great Britain \& Library Association.

Saltman, J. (1987). Modern Canadian children's books. Toronto: Oxford University Press. 
Sturges, P., \& Neill, R. (1998). The quiet struggle: information and library services for the people of Africa. $2^{\text {nd }}$ ed. London: Mansell.

Taylor, N., \& Vinjevold, P. (1999). Getting learning right. Johannesburg: Joint Education Trust.

United Kingdom. Department of National Heritage. (1995) Investing in children: the future of library services for children and young people. London: HMSO.

Williams, G. (1988). Children's books in teacher education at the University of Sydney. Signal, 56, 133-141.

Wray, D., Bloom, W., \& Hall, N. (1989). Literacy in action. London: Falmer Press. 